\title{
Short Message Service Fish Notification Microcontroller System as an Alternative Tool for Income Generation Fisherman
}

\author{
THF.Harumy ${ }^{1}$, AD Tarigan ${ }^{2}$ \\ \{hennyharumy@hotmail.com $\left.{ }^{1}\right\}$ \\ ${ }^{1}$ Computer Science,University Pembangunan Pancabudi,gatot Subroto Street, Medan,Indonesia \\ ${ }^{2}$ Electronica,University Pembangunan Pancabudi,gatot Subroto Street, Medan,Indonesia
}

\begin{abstract}
The problems faced by fishermen are uncertain fish catches. This is due to uncertain weather so that fishers cannot go to sea. The purpose of this study is to make an alternative catching device for Short Message Service based fishers who function as an effective and efficient alternative fishing tool placed on the coast and an alternative income for fishers. Fads are made consisting of a collection of Bamboo and seaweed found on the coast of the coast or called Bagan or Rumpon. While the tools used to make RA microcontroller devices are Fish Finder, Intel Galileo / Arduino, Global System for Mobile Communications modules, solar cells, sensors, batteries. With the application of RA microcontrollers so that charts located on the coast work effectively and efficiently with Short Massage Service notifications so that fishermen do not need always to see whether the chart is full or not enough just waiting for Short Message Service notifications so they can reduce costs by up to $50 \%$ in fuel usage for checking chart and efforts to increase revenue $30-50 \%$. The expected that later RA Microcontroller could be made into products that are value added for fishers and increase fishermen's income.
\end{abstract}

Keyword: RA Microcontroller, Rumpon, Bagan, Short Message Service, IoT, Income

\section{Introduction}

The problem faced by fishermen today is the uncertain and unpredictable fish catches. Fishers can sometimes get much fish, but sometimes the brand does not get any fish. Consider This is due to uncertain weather so that fishers cannot go to sea so that it can be said that the fishing community lives in a poverty line (Agunggunanto, 2012). Likewise from the economic side of the community in this village can be said to be classified as a weak economy with below-average income. - Average and does not have good business management. Regarding education it is also classified as still low, in this village, there are still many children who do not feel like school in general. Based on observations of researchers in the field, the fishermen in question are fishermen who have their it boats/boats used to find fish in the sea, while fishers are workers who work for fishers. He does not have his boat but works for fishers who have shipped to fish in the sea. The fishermen themselves are further divided into fishers who make arrests at sea and fishers who do the marketing of fish catches. This fisherman is called the community as a fisherman toke. So that a significant change needed from this hazardous condition. In this effort according to previous research with the existence of new technology can increase fishermen's income (Muhammad Iqbal, Muhammad Zarlis, T.H.F Harumy, 2017),(Wimatra et al., 2016) and (Nasution et al., 2016) Basically all this time fishermen have an alternative fishing gear that is Rump on which is placed on the Coastal Coast, but the problem that occurs is that the fishermen have to go back and forth in the observation of the researcher usually they check in the morning but it is uncertain if there are fish caught so 
much material burn. From these results, a Microcontroller is used to help fishers get SMS notifications if the Fads are full, fishers will get notifications from RA microcontrollers placed on fishermen's Figs / Fads. The problem formulation of this research is how to design a Microcontroller RA as an alternative fishing tool for fuel efficiency and increase fisherman income. While the objective is to design a microcontroller RA as an alternative fishing tool for fuel efficiency and increase non-revenue income, and the hypothesis of this research is RA Microcontroller as an alternative fishing tool for fuel efficiency and increase fisherman income.

\section{Literature Review}

From previous research, it that fishers know, fish farmers, and aquaculture farmers are social groups that are directly related to the management of coastal and marine resources). The application of technology has a positive effect on fishermen's income such as research (Harumy T.H.F., 2018),(Wasserman, 2010) stated that the application of mobile applications helped increase fishermen's income. Other than that. (Boonnuddar and Wuttidittachotti, 2017)(Abrahamsson et al., 2017)(Al-jabri, 2012)(Taylor and Tilley, 1984), (Henny Febriana Harumy and Tarigan, 2018) Besides, there are also examples of the application of other technologies to describe a map of fishing lane zones in the waters of West Kalimantan. The material and data in this study are spatial data, tidal data and legislation related to fishing zoning. The method used is a Geographic Information System approach with spatial analysis techniques (Nurdin, Azbas Taurusman and Yusfiandayani, 2012). (Machado et al., 2012)(McClanahan and Mangi, 2001),(Danovitch and Keil, 2004)(Froese, 2004),(Vandeperre et al., 2011),(Vandeperre et al., 2011),(Martell and Froese, 2013),(Hilborn et al., 2003),Rump on is a tool for fishing; Fads function to attract groups of fish to gather around them. In the short term, Fads can increase the production of catches, the efficiency, and effectiveness of fishing operations. For the following pictures:

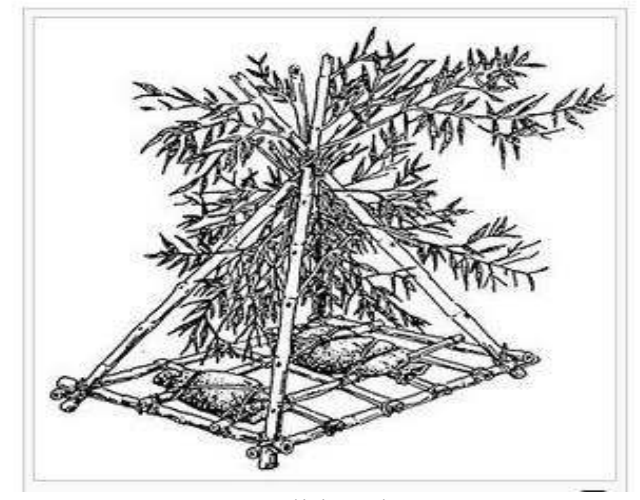

Fig. 1. Traditional Rumpon

Understanding it is also referred to as income, namely the return received by all households in the community layer in a country/region, from the surrender of factors of production or after carrying out economic activities. The income is used by the community to meet consumption needs, and the rest is savings to meet the future. 


\section{Research Method}

Method of collecting data. The data collection method used is:

- Literature study

This stage is carried out by searching various scientific journal sources, and the internet to obtain data that supports and strengthens Microcontroller design and system analysis problems.

- Observation

For Observation Researchers conducted observations in one of the coastal areas of North Sumatra Indonesia. Then the researchers collected information about it.

- System Design Method

The method used is waterfalls(Hotle, 2008).

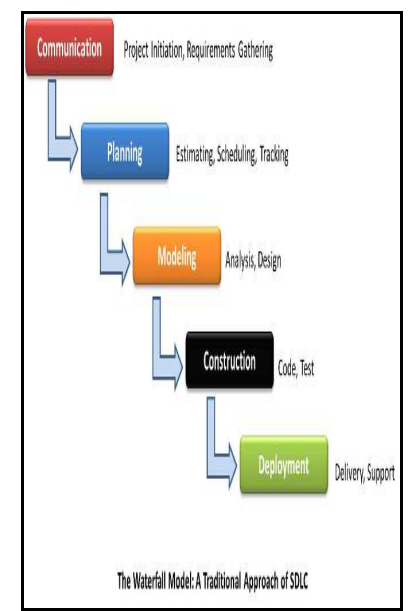

Fig. 2.Waterfalls Method

Consisting of Engineering System Modeling begins with looking for the needs of fishers and their problems from the entire system that will apply in the form of software and hardware.

- Analysis

The process of finding the needs intensified and focused on software. To find out the nature of the program to be made, both Arduino, fish finder, solar cell, casing, Global System for Mobile Communications module and all the functions of each component, how to use it.

- Design

This process is used to convert the above needs into representation in the form of "blueprint" software and hardware display hardware. 


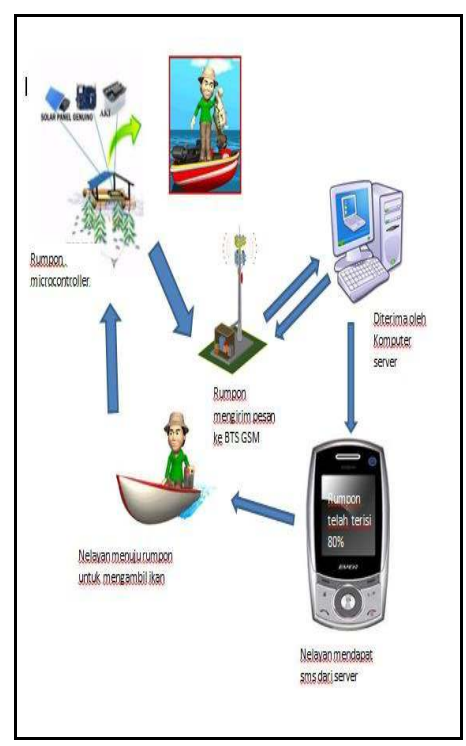

Fig. 2. Design

- Coding

This stage is the implementation of the design phase which is technically done by the programmer after coding is carried out on the tool / Arduino which have designed according to the needs of Fads(Holzer and Ondrus, 2011).

- Testing

This stage is trying the tools/systems that we have coding and designing. From there it will be seen whether this tool works according to its function and this research documented in each process.

- Maintenance

After the Microcontroller has been a test, Maintenance of software and hardware is needed, including development, because the software and hardware that made are not always just like that.

\section{Result And Discuss}

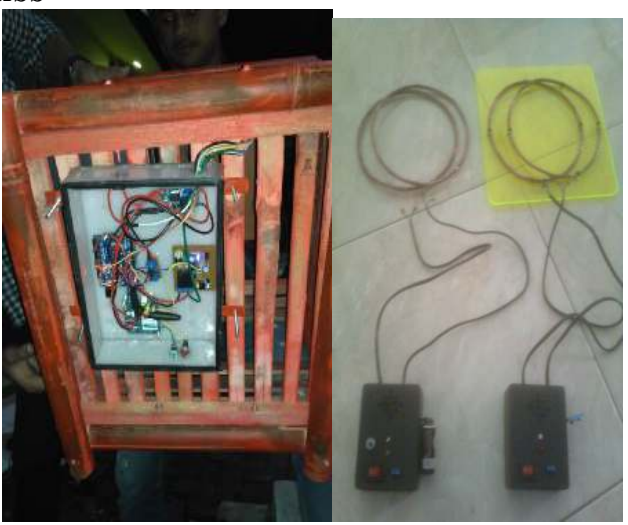




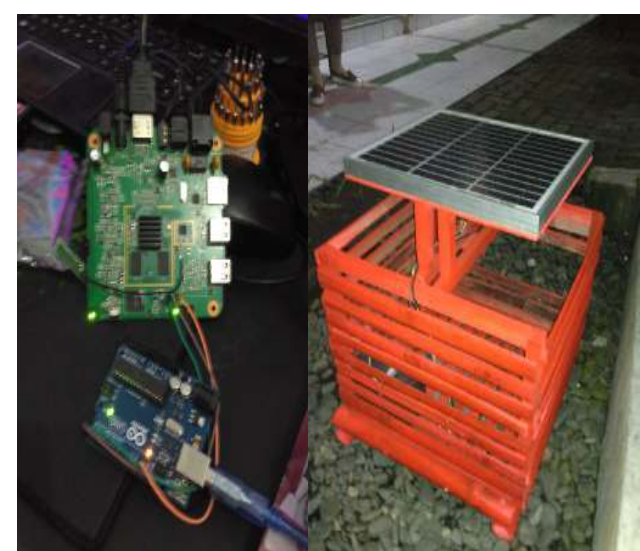

Fig. 4. Rumpon Microcontroller

- Black Box testing

Table 1. Black Box testing

\begin{tabular}{|c|c|c|c|}
\hline & Equipment & Justification & $\begin{array}{l}\text { Testing with Black } \\
\text { Box }\end{array}$ \\
\hline 1 & Arduino & Micro controller & Succsefull \\
\hline 2 & $\begin{array}{l}\text { MOdul } \\
\text { GSM }\end{array}$ & microcontroller & Succsefull \\
\hline 4 & Solarcell & microcontroller & Succsefull \\
\hline 5 & Aki & microcontroller & Succsefull \\
\hline 6 & Cabel & microcontroller & Succsefull \\
\hline 7 & handphone & $\begin{array}{l}\text { Microcontroller and } \\
\text { SMS }\end{array}$ & Succsefull \\
\hline 8 & Wooden box & Box & Succsefull \\
\hline
\end{tabular}




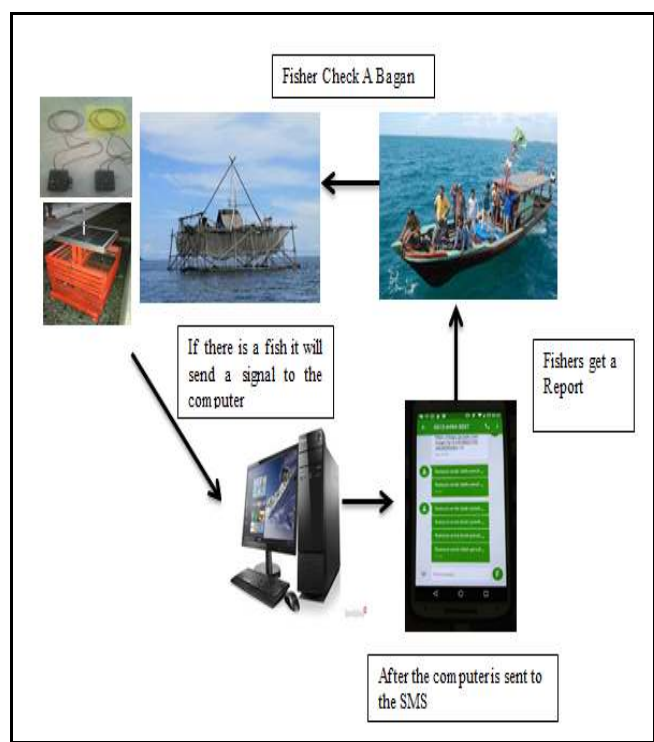

Fig.5. Mechanism Implementation Rumpon

After 1 Month in Trial the results of observations of the system can be seen from the results of the efficiency table which can be seen as follows:

Table 2: Observation Result After Implementation

\begin{tabular}{|c|c|c|c|}
\hline \multirow{2}{*}{$\begin{array}{l}\text { Automatic } \\
\text { equipment }\end{array}$} & \multicolumn{3}{|l|}{ Observation Result } \\
\hline & $\begin{array}{l}\text { Before Use } \quad \text { A } \\
\text { Microcontroler }\end{array}$ & RA & After Use A RA Microcontroler \\
\hline Fuel / Solar to Fuel Boat & $\begin{array}{l}20 \text { Liter } / \text { Week } \\
20 * 5500=110.000\end{array}$ & & $\begin{array}{l}15 \text { Liter / week } \\
15 * 5500=82.500\end{array}$ \\
\hline Rent Boat & $\begin{array}{l}\text { Every Day } \\
50.000 \times 30=1.500 .000\end{array}$ & & $\begin{array}{l}\text { Every } 2-3 \text { days } \\
50.000 \times 15=750.000\end{array}$ \\
\hline Fish Checking & 1 Day Time( every Days ) & & $\begin{array}{l}\text { Not Every Day depends on notifications from } \\
\text { SMS }\end{array}$ \\
\hline $\begin{array}{l}\text { Percentage of Fuel Savings } \\
\text { and Boat Rentals }\end{array}$ & $\begin{array}{l}1.500 .000+110.000 \\
1.610 .000 \\
100 \%\end{array}$ & & $\begin{array}{l}750.000+82.500=832,500 \\
50 \%\end{array}$ \\
\hline
\end{tabular}

From the results of the observation, can be seen that the result is a reduction/fuel efficiency and a boat rental of about $30-50 \%$ after the use of RA microcontroller. However, this microcontroller still needs to be improved considering that this system place in a chart that is vulnerable to damage due to seawater and also storms. So it still needs to be done further.

\section{Conclusion}

The conclusion is that the microcontroller RA can be used as an alternative catch tool that can be used for efficiencies around $30-50 \%$ 


\section{Acknowledgements}

Thanks to Kemristekdikti who helped finance the RA microcontroller system design.

\section{Reference}

[1] Abrahamsson, P. et al. (2017) 'Mobile-D : An Agile Approach for Mobile Application Development', International Journal of Service Industry Management. doi: 10.1145/1028664.1028736.

[2] Agunggunanto, E. Y. (2012) 'Analisis Kemiskinan Dan Pendapatan Keluarga Nelayan Kasus Di Kecamatan Wedung Kabupaten Demak, Jawa Tengah, Indonesia', Jurnal Dinamika Ekonomi Pembangunan.

[3] Al-jabri, I. M. (2012) 'Mobile Banking Adoption: Application of Diffusion of Innovation Theory', Electronic Commerce Research. doi: 10.1007/s00423-010-0711-5.

[4] Boonnuddar, N. and Wuttidittachotti, P. (2017) 'Mobile Application', in Proceedings of the International Conference on Big Data and Internet of Thing - BDIOT2017. doi: $10.1145 / 3175684.3175714$.

[5] Danovitch, J. H. and Keil, F. C. (2004) 'Should you ask a fisherman or a biologist?: Developmental shifts in ways of clustering knowledge', Child Development. doi: 10.1111/j.1467-8624.2004.00714.x.

[6] Froese, R. (2004) 'Keep it simple: Three indicators to deal with overfishing', Fish and Fisheries. doi: 10.1111/j.1467-2979.2004.00144.x.

[7] Harumy T.H.F., H. M. Z. N. A. (2018) 'Aplikasi Mobile Zagiyan ( Zaringan Digital Nelayan ) Dalam Menunjang Produktivitas Dan Keselamatan , Dan Kesehatan Nelayan', IT Journal Research and Developmen, 2(2), pp. 52-61.

[8] T.H.F Harumy, T. and Tarigan, A. D. (2018) 'Trap (Rumpon) environment friendly based on microcontroller to increase fisherman's revenue', Journal of Advanced Research in Dynamical and Control Systems, 10(4 Special Issue), pp. 1576-1580.

[9] Hilborn, R. et al. (2003) 'State of the World's Fisheries', Annu. Rev. Environ. Resour. doi: 10.1146/annurev.energy.28.050302.105509.

[10] Holzer, A. and Ondrus, J. (2011) 'Mobile application market: A developer's perspective', Telematics and Informatics. doi: 10.1016/j.tele.2010.05.006.

[11] Hotle, M. (Gartner) (2008) 'Waterfalls, Products and Projects : A Primer to Software Development Methods', Gartner.

[12] Machado, O. J. A. et al. (2012) 'Fisherman search procedure', in Lecture Notes in Computer Science (including subseries Lecture Notes in Artificial Intelligence and Lecture Notes in Bioinformatics). doi: 10.1007/978-3-642-34654-5_30.

[13] Martell, S. and Froese, R. (2013) 'A simple method for estimating MSY from catch and resilience', Fish and Fisheries. doi: 10.1111/j.1467-2979.2012.00485.x.

[14] McClanahan, T. R. and Mangi, S. (2001) 'The effect of a closed area and beach seine exclusion on coral reef fish catches', Fisheries Management and Ecology. doi: 10.1046/j.1365-2400.2001.00239.x.

[15] Muhammad Iqbal, Muhammad Zarlis, Harumy, T. H. . . (2017) 'Inovasi Aplikasi Check In Spot Nelayan Untuk Binaan Kecamatan Bagan Deli Medan', In. Jayapura: Seminar Nasional Aptikom (Semnastikom), Pp. 1-6.

[16] Nasution, D. et al. (2016) 'A classification method for prediction of qualitative properties of multivariate EEG-P300 signals', Proceedings of the 2015 International Conference on Automation, Cognitive Science, Optics, Micro Electro-Mechanical System, and Information Technology,ICACOMIT 2015, pp. 82-86. doi: 
10.1109/ICACOMIT.2015.7440180.

[17] Nurdin, E., Azbas Taurusman, A. and Yusfiandayani, R. (2012) 'Optimasi jumlah rumpon, unit armada dan musim penangkapan perikanan tuna di perairan prigi, jawa timur', J. Lit. Perikan. Ind.

[18] Taylor, R. H. and Tilley, J. A. V. (1984) 'Stoats ( Mustela erminea) on Adele and Fisherman Islands, Abel Tasman National Park, and other offshore islands in New Zealand.', New Zealand Journal of Ecology.

[19] Vandeperre, F. et al. (2011) 'Effects of no-take area size and age of marine protected areas on fisheries yields: A meta-analytical approach', Fish and Fisheries. doi: 10.1111/j.1467-2979.2010.00401.x.

[20] Wasserman, A. I. (2010) 'Software engineering issues for mobile application development', in Proceedings of the FSE/SDP workshop on Future of software engineering research - FoSER '10. doi: 10.1145/1882362.1882443.

[21] Wimatra, A. et al. (2016) 'Backpropagation model for Bidikmisi recipients', Internetworking Indonesia Journal, 8(2). 